\title{
„Depositional setting of the Oligocene sequence of the Western Carpathians in the Polish Spisz region - a reinterpretation based on integrated palynofacies and sedimentological analyses" - Discussion
}

\author{
Przemysław GEDL ${ }^{1, *}$ \\ 1 Institute of Geological Sciences, Polish Academy of Sciences, Research Center in Kraków, Senacka 1, 31-002 Kraków, \\ Poland \\ Gedl, P., 2018. „Depositional setting of the Oligocene sequence of the Western Carpathians in the Polish Spisz region - a re- \\ interpretation based on integrated palynofacies and sedimentological analyses" - Discussion. Geological Quarterly, 62 (3): \\ 745-750, doi: 10.7306/gq.1422
}

\section{INTRODUCTION}

In their recent paper, Filipek et al. (2017) provided some data on age (dinoflagellate cyst biostratigraphy) and sedimentary setting (sedimentological and palynofacial analysis) of the Podhale Flysch (Central Carpathian Paleogene) from the Polish Spisz (their fig. 1). They carried out their integrated studies on the middle part of the Podhale Flysch succession - the upper part of the Szaflary beds through the lower part of the Chocholów beds. These studies, as stated in Introduction, "...allow for a new approach to the knowledge on the CCPB with regard to stratigraphy, depositional palaeoenvironment, and changes during deposition". Authors accented the inconsistency of some of previous studies (biostratigraphical in particular), which provoked them to undertake their studies in order to reinterpret the depositional setting. In my opinion, however, it is hardly possible to find new reinterpretations, and those presented are frequently based on erroneous, commonly random and not complete data and interpretations; none of them are compared nor discussed with previous results. Below, these controversies are briefly presented.

\section{GEOLOGICAL SETTING}

The Podhale Basin was part of the Central Carpathian Paleogene Basin (Inner Carpathians). Its sedimentary succession is traditionally divided into two parts: the lower, platform carbonates (the so-called Nummulitic Eocene; also known as the Tatra Eocene; Middle-Upper Eocene), and the upper part representing a thick flysch succession (the so-called Podhale

\section{*E-mail: ndgedl@cyf-kr.edu.pl}

Received: March 5, 2018; accepted: March 6, 2018; first published online: July 16, 2018
Flysch; Oligocene-lowermost Miocene). Filipek et al. (2017) use the term "basin" in an improper lithostratigraphic context. This may lead to false understanding, particularly by a reader not familiar with regional Central Carpathian geology. Sentences like "the Podhale Basin is ... underlain by Nummulitic Eocene" and "The Podhale Basin is composed of ... Podhale Flysch", are incorrect. Inconsistent lithostratigraphic terminology may be the reason of the authors' inconclusive referring to the age of the succession in question by comparing various authors' results in this field.

Filipek et al. (2017) present also a careless approach to citations, which can again mislead the reader. For example, most of papers, cited in Introduction to show the micropalaeontological studies of the Podhale Flysch in the Spisz area, refer in fact either to the underlying Nummulitic Eocene or reworked large foraminifera (Bieda, 1946, 1948, 1959; Alexandrowicz and Geroch, 1963), the Podhale Flysch in the Orawa area (Gedl, 1995) or to the Eocene-Oligocene transition in the Outer Carpathians (Gedl, 1999). Similar careless referring applies to sedimentological studies when Filipek et al. (2017: p. 859) highlight a pioneering nature of their study in the Spisz area: among papers referred to sedimentological aspects of the Podhale Flysch (not Tatra Eocene), most refers also to the Spisz area; moreover, many of them were based on studies from exactly the same sections in Kacwinianka and Łapszanka (see Radomski, 1958: fig. 23; Grzybek and Halicki, 1958: fig. 5; Marschalko and Radomski, 1960: pl. 31; Pieńkowski and Westwalewicz-Mogilska, 1986: fig. 6).

\section{BIOSTRATIGRAPHY}

\section{AGE}

Filipek et al. (2017) studied 25 samples from the upper Szaflary beds-lower Chochołów beds interval, but only a few yielded dinoflagellate cyst assemblages that, according to the authors, allow precise, Early Rupelian dating (see their fig. 3). 
Unfortunately, authors did not carry out a reliable justification for this dating. Summarizing their biostratigraphical interpretations, Filipek et al. (2017) surprisingly concluded: "Based on the biostratigraphic analysis using dinoflagellate cysts, the age of the deposits (...) can be determined at the Early Rupelian. The presented results are completely different from the previous biostratigraphic determinations". It remains, however, completely enigmatic to the reader, what the authors mean by these "completely different" results, as Filipek et al. (2017) totally omitted results of previous micropalaeontological studies of the Podhale Flysch; they neither compared nor discussed their results with the previous ones.

Filipek et al. (2017) suggested Early Rupelian age of these samples based on the co-occurrence of several species, although most of them has ranges far beyond Oligocene (Williams and Bujak, 1985; Stover et al., 1996; Williams et al., 2004): Caligodinium amiculum (Paleocene-Early Miocene), Spiniferites ramosus (earliest Cretaceous-recent), Deflandrea phosphoritica (earliest Eocene-Early Miocene), Hystrichokolpoma rigaudiae (earliest Eocene-Pleistocene), Spiniferites pseudofurcatus (Late Paleocene-Late Miocene), Thalassiphora pelagica (Maastrichtian-Chattian), Reticulatosphaera actinocoronata (mid-Priabonian-Pleistocene). Wetzeliella articulata, $W$. gochtii and $W$. symmetrica are deemed more reliable for Rupelian dating, but omitting their high intraspecific variability, their known stratigraphic ranges are highly related to palaeolatitudes and they also go beyond the Rupelian.

$W$. articulata is well-known from older, Eocene strata (e.g., Châteauneuf and Gruas-Cavagnetto, 1978; Williams and Bujak, 1985; Köthe and Piesker, 2008; Vasilyeva, 2013; Gedl, 2014) and ranges to the lower (e.g., Stover and Hardenbol, 1993) and mid-Upper Oligocene (Sachsenhofer et al., 2010; Chattian: Costa and Downie, 1976: fig. 3; NP24: Mao et al., 2004; NP23: Soliman, 2012). W. symmetrica is predominantly known from the Oligocene (LO: lower NP22: Van Simaeys et al., 2005; NP21/22 transition: Köthe and Piesker, 2008; uppermost NP21: Śliwińska et al., 2012; HO: lower Chattian: Köthe, 1990; NP24/25 transition: Van Simaeys et al., 2005; upper NP24: Köthe and Piesker, 2008; lower NP25: Śliwińska et al., 2012; top of Chattian: Fensome et al., 2009; see also Pross, 2001: fig. 1), but it was also reported from Eocene strata (e.g., Châteauneuf and Gruas-Cavagnetto, 1978; Köthe, 2009; Vasilyeva, 2013; Gedl, 2014). Filipek et al. (2017) ignored the occurrence of both species in the younger part of the Podhale Flysch (Gedl, 2000), which supports their Chattian range (or they are reworked).

The range of $W$. gochtii is limited to the Oligocene; its LO data are usually reported from the lower-middle Rupelian (e.g., NP23: Williams and Bujak, 1985; 33.6-33.2 Ma - NP21/22 transition: Eldrett et al., 2004; lower part of NP22 of Van Simaeys et al., 2005; upper NP22: Köthe and Piesker, 2008; uppermost NP21: Śliwińska et al., 2012; Mediterranean: 33.1 $\mathrm{Ma}$ - uppermost NP21: Pross et al., 2010, see also Brinkhuis and Biffi, 1993; Wilpshaar et al., 1996; see also Kempf and Pross, 2005), whereas HOs are from the lower Chattian (Schiøler, 2005; NP25 of Van Simaeys, 2005; lower NP25: Śliwińska et al., 2012; see also Pross, 2001: fig. 1). Williams et al. (2004) report its mid-Rupelian (32.8 Ma)-mid-Chattian (26.6 Ma) range at Northern Hemisphere mid-latitudes. Bujak (in Van Couvering et al., 1981) and Gedl (2004a) suggested its uppermost Eocene (uppermost part of the NP19-20 in the former) LO in the Carpathians (see also Gedl, 2005: fig. 2).

Summarizing, the co-occurrence of all these species indicates rather the lower-middle Rupelian-lower Chattian than the lower Rupelian as suggested by Filipek et al. (2017). However, perhaps the most important species for dating these de- posits - Chiropteridium lobospinosum - was completely omitted by the authors. Its occurrence in the lowermost part of the Zakopane beds (samples 414a and 648) excludes lower Rupelian age of this unit and the overlying Chochołów beds. The range of $C$. lobospinosum, although also highly related to palaeolatitudes (as it is the case with $C$. galea, which first appeared $33.5 \mathrm{Ma}$ at mid-latitudes and $31 \mathrm{Ma}$ in equatorial areas: Williams et al., 2004), begins in the lower (but not lowermost) Rupelian (North Sea: NP21/22 transition in Eldrett et al., 2004; uppermost NP22-lowermost NP23 of Van Simaeys et al., 2005; NP23: Köthe and Piesker, 2008; NP22: Śliwińska et al., 2012; Mediterranean: NP23-NP25: Biffi and Manum, 1988; NP23-24: Wilpshaar et al., 1996; common occurrence in lower NP24: Pross et al., 2010). Similar assemblages, with $C$. lobospinosum, $W$. symmetrica and $W$. gochtii, were described from the Alpine-Carpathian belt, all being dated Rupelian (mainly upper Rupelian; NP22-24)-lower Chattian (Austrian Molasse Basin, Alpine Foreland Basin: Sachsenhofer et al., 2010; Soliman, 2012; Western Carpathians: Barski and Bojanowski, 2010; Eastern Carpathians: Țăbăra, 2017).

In the Mediterranean-Alpine sections, the LO of W. gochtii usually preceded the LO of C. Iobospinosum (Pross et al., 2010; Sachsenhofer et al., 2010; Soliman, 2012). Therefore, the occurrence of $C$. lobospinosum in the lowermost part of the exposed Szaflary beds (Gedl, 2000) was the reason of its mid-Rupelian dating. Filipek et al. (2017) omitted also the stratigraphical significance of Rhombodinium sp. B (557pod), Wetzeliella sp. A (706), and Caligodinium? sp. B (701, 8Ał); these formally undescribed species (Gedl, 2000) were all reported from the Zakopane beds and overlying strata (upper Rupelian-lower Chattian). Barski and Bojanowski (2010) found these two Wetzeliellacean species in samples dated upper Rupelian-lower Chattian; it was not discussed by Filipek et al. (2017).

Neither had they discussed any previous results (Gedl, 2000: dinoflagellate cysts; Garecka, 2005: calcareous nannoplankton), which clearly suggest the Rupelian (but not lowermost) and the NP24 Zone (upper Rupelian-lower Chattian, see Berggren et al., 1995; Luterbacher et al., 2004), respectively. These results clearly show that age interpretation given by Filipek et al. (2017) is erroneous. Possibly, the lowermost part of the Szaflary beds (2410-2970 m) of the Chochołów IG 1 borehole represents the lower Rupelian, as it is missing Chiropteridium (Gedl, 2000). From this part of the Szaflary beds, Garecka (2005) reported an impoverished, poorly preserved assemblage that might be indicative for the mid-Rupelian NP23 Zone or the upper part of the NP22 Zone (Late Eocene calcareous nannoplankton and foraminifera found in this intervals are presumably reworked; see Dudziak in Jaromin et al., 1992a, b, and Gonera in Sokołowski, 1992). In the outcrops, also in the Spisz area, C. Iobospinosum occurs in the stratigraphically lowermost Szaflary beds (Gedl, 2000).

\section{REDEPOSITION}

There are two common processes during flysch sedimentation: redeposition (resedimentation) and recycling (reworking). These terms are frequently used interchangeably (see Jackson, 1997), but they are not synonyms. Redeposition (resedimentation) generally refers to approximately synsedimentary relocation of particles (fossils, mineral grains, etc.) from one sedimentary setting to another, usually under the influence of either gravity (for example transportation of shallow-marine, near-shore organisms into deep, abyssal plains by a turbidite current) or hydrodynamics (subaqueous currents, waves, etc.). 
Recycling (reworking), in turn, means a process by which particles are removed or displaced from their original rock (older), transported, deposited and incorporated into a new, younger sedimentary rock. Filipek et al. (2017) stated: "Dinoflagellate cyst redeposition mainly takes the form of co-occurrence of taxa with discordant stratigraphic ranges", which means that they use these terms in the latter meaning. However, in some cases, as for example referring to the appearance of near-shore taxa in oceanic settings, Filipek et al. (2017: p. 864) also use the same term "redeposition" (meaning: "resedimented"), which can mislead the reader.

It is not a problem to distinguish reworked (recycled) dinoflagellate cysts with a known pre-Oligocene stratigraphic range: Filipek et al. (2017) list two Jurassic forms evidently reworked. But the problem begins when long-ranging species are considered. Filipek et al. (2017) decided to solve this problem using the state of preservation as a determinant of reworking (but not resedimentation). This, however, in my opinion, is a significant simplification based on the assumption that recycled forms are always much worse preserved than the in situ ones. Particularly in case of Podhale Flysch strata, which show a clear trend of gradual worsening of palynomorph preservation from west to east, this phenomenon was related to a supposed increasing distance from the source area located to the nowadays west (Gedl, 2000: figs. 82, 84). However, Środoń et al. (2006) linked it with increasing temperature due to growing subsidence and sedimentary cover in the Spisz area (cf. their figs. 5 and 9). Although Filipek et al. (2017) noted better preserved palynomorphs in the western part of their study area (Łapszanka), but they neither commented this nor compared with results of previous studies. Moreover, their assumption that worse preserved palynomorphs are reworked may lead to confusion as frequently reworked microfossils are better preserved than the in situ ones (see e.g., Batten, 1991). Particularly in flysch strata, where transportation processes (resedimentation) and/or early post-depositional processes (e.g., pyrite crystal growth) can damage in situ fossils to a much greater extent than reworked fossils that are commonly protected by sediment coating. An example could be the Eocene dinoflagellate cysts from a secondary deposit within the Rupelian Szaflary beds in the Leśnica section (Gedl, 2004b): although variously preserved, many of them are better preserved than in situ forms from the host flysch deposits (cf. Gedl, 2000). Filipek et al. (2017: fig. 4G) showed a specimen of Tityrosphaeridium (now Cordosphaeridium) sp. as an example of poorly preserved reworked dinoflagellate cyst. However, in my opinion, this is rather a specimen with an apical archaeopyle and a prominent antapical process (Hystrichokolpoma?); moreover, its preservation is not worse than of specimens recognized as in situ and shown in their figure 4.

Filipek et al. (2017) introduced a pioneering method to the Podhale Flysch studies - the UV-excited fluorescence observations. They used this method to distinguish recycled (not resedimented) dinoflagellate cysts and to determine the origin of amorphous organic matter (for details of this method see, i.a., van Gijzel, 1967; Tyson, 1995) in four samples selected. In the first case, Filipek et al. (2017) noted a different brightness of ultraviolet excited specimens: dull specimens were treated as recycled, whereas bright ones - as being in situ. However, this interpretation was presented in a slightly unclear way and, in my opinion, insufficiently supported by evidence, it was not discussed and, what is most surprising, it was completely omitted in further palaeoenvironmental interpretations. Authors mention a group of poorly preserved dinoflagellate cysts that show dull autofluorescence, which consists of "stratigraphically older species and species with long stratigraphic ranges" - but no species list is given, except for an example of Deflandrea phosphoritica that belongs to the "long stratigraphic range" group. From earlier chapters, the reader can deduce that the only true "older species" among the taxa determined are Jurassic Ctenidodinium and Nannoceratopsis. However, none of them occurs in samples investigated for fluorescence (see their table 1)... The second group distinguished by Filipek et al. (2017) contains well-preserved specimens that show bright fluorescence colours, which are interpreted as in situ. But again, except for a single example of Rhombodinium, no species list is given. And this information would be crucial for precise age determination of the deposits in question. Moreover, including Rhombodinium to the in situ group, authors do not specify which species they have in mind (there are at least three: $R$. freienwaldensis, $R$. longimanum, and $R$. sp. B). Interestingly, Filipek et al. (2017) noted that Rhombodinium specimens show bright fluorescence light independently of their preservation state. Regrettably, this very important information for the application of palynomorph ultraviolet light observations is not further elucidated.

Another important observation made by Filipek et al. (2017) was finding, in the same sample, representatives of the same species (Deflandrea phosphoritica) showing various preservation states. Although it was not stated in text, the reader may guess that poorly preserved specimens (in contrast to Rhombodinium) show dull fluorescence light (as shown in their fig. 7G, $\mathrm{H}$; cf. with fig. 7E, F). The authors interpreted the "dull" specimens as recycled, although they did not report their frequency. I can guess their proportion to "bright" specimens ("in situ") is significant in their samples, as Filipek et al. (2017) referred to Deflandrea "blooms" described in the Podhale Flysch (Gedl, 2000) in the following way: "Such high abundance of Deflandrea is rather related to the redeposition of this taxon, which may cause erroneous environmental interpretations". Surprisingly, in their chapter dedicated to palynological indicators of palaeoenvironment, they list three major dinoflagellate cyst palaeoenvironmental groups, one of which consisting chiefly of Deflandrea specimens. On their basis, they reconstruct sedimentary setting of the deposits in question (Filipek et al., 2017: p. 864), without noting that a few pages away they treat them as recycled, and announce their omitting from further interpretation (pp. 870-872); finally, in the conclusions, they again mention Deflandrea as one of palaeoenvironment indicators (p. 874).

Beside this inconsequence, Filipek et al. (2017) did not discuss the other possible explanation of different intensities of fluorescence light of representatives of the same species. Some other factors may influence its intensity: oxidation, pyrite crystallization, bioturbation, transportation, etc. (e.g., Foster et al., 1986: p. 147: fide Tyson, 1995). A possible explanation might be the mixing of dinoflagellate cysts resedimented (but not recycled!) by turbidite currents from near-shore settings, and of those, which inhabited waters directly above the deposition site. In this case, however, it is not certain, which group would be characterized by duller fluorescence light. A valuable clue to solve this problem would be a full list of "dull" species.

\section{PALAEOENVIRONMENT AND SEDIMENTARY SETTING}

\section{SEDIMENTATION RATE}

Filipek et al. (2017) calculated a precise sedimentation rate of the analysed deposits at $1600 \mathrm{~m} / \mathrm{Ma}$ (1.6 mm per year) without specifying how this value was received. The authors neither calculated the true thickness of strata they studied 
(omitting the degree of compaction) nor precisely dated them. In my opinion, such a value is a result of incorrect dating of the interval in question (see above). Without knowing the precise time interval when a given sequence was deposited (the term "Early Rupelian" is vague), calculation of its sedimentation rate makes no sense (the Rupelian lasted $5.45 \mathrm{Ma}$ according to Luterbacher et al., 2004). Filipek et al. (2017) neither compared their interpretation with the previous ones nor discussed them. For example Soták (1998) calculated approximate sedimentation rates of the Central Carpathian Paleogene as follows: $800 \mathrm{~m} / \mathrm{Ma}$ for the Šambron Fm. (Szaflary beds; duration: $\sim 3 \mathrm{Ma}$ ), 80-160 $\mathrm{m} / \mathrm{Ma}$ for the mud-rich accumulation (Huty Fm./Zakopane beds) during $\sim 5 \mathrm{Ma}$, and 320-370 m/Ma for the sand-rich flysch-molasse deposition of the Zuberec and Biely Potok formations (Chochołów and Ostrysz beds) that lasted $\sim 7 \mathrm{Ma}$.

\section{PALAEOBATHYMETRY}

It is very difficult to determine precisely the basin depth during flysch deposition, especially in an oxygen-depleted benthic environment almost devoid of benthic fossil communities as it is in the case of the Podhale Flysch. Despite this, Filipek et al. (2017) suggested a shallow-water sedimentary setting of the lower part (upper Szaflary beds-lower Chochołów beds) of the Podhale Flysch in Spisz based on palynological and sedimentological premises. Although the authors did not specify the absolute value of water depth, but the reader can deduce it was not deeper than 40-50 m. This very interesting, but also controversial conclusion, was not referred, unfortunately, to the previous reconstructions, which almost unanimously support a deep-water, basinal sedimentary setting of the flysch deposits of the Central Carpathian Paleogene (e.g., Marschalko, 1964; Soták, 1998; Sotak et al., 2001; Starek and Fuksi, 2017).

Palynological evidences, particularly planktic dinoflagellate cysts that, according to Filipek et al. (2017), point to a shallow-water setting, cannot serve as a direct clue in this type of reconstructions (although commonly incorrectly used in bathymetrical interpretations, e.g., Gedl, 2000: p. 150). Particularly in case of turbiditic sedimentation when immense resedimentation of near-shore forms into deeper parts of the basin can be expected (see Gedl, 2000: p. 143, 150). Hence, their frequent occurrence in the Podhale Flysch reflects rather sedimentation mode than true basin depth. Filipek et al. (2017) omitted the presence of offshore Impagidinium and Nematosphaeropsis in the Podhale Flysch (Gedl, 2000), which, although highly dispersed among near-shore species, may be the trace of the only pelagic elements (note: but they cannot be treated as absolute water-depth indicators). The same refers to palynofacies distribution in turbiditic deposits, where frequency changes of particular element groups (e.g., cuticles) reflect the intensity of resedimentation and distance from the source area rather than basin depth; their proportions differ significantly in a single turbidite sequence (Gedl and Suruło, 2005).

The most reliable indicator of shallow-water conditions of Podhale Flysch deposition presented by Filipek et al. (2017) is the hummocky cross-stratification structure (see Swift et al., 1983: fig. 1; Dumas et al., 2005), which is a sedimentary structure traditionally believed to be formed by oscillatory water movement involved by storm-generated waves (Harms et al., 1975). This makes that they are treated as an indicator of shallow-water conditions, as storm wave-base reaches typically 15-40 m (e.g., Allaby, 2008). According to Dumas and Arnott
(2006), hummocky cross-stratification appears at a water depth of 13-50 m (at shallower depths it is replaced by swaley cross stratification), Selley (2000: p. 151) reports recent hummocky cross-stratification from 1-40 m deep water. However, some authors suggest possible greater depths of hummocky crossstratification formation. Shanmugan (2012: p. 148) observed hummocky cross-stratification at large depths in the North Sea and the Norwegian Sea. Mulder et al. (2009) reported hummocky cross stratification-like structures from deep-sea (below $1000 \mathrm{~m}$ depth) turbidites in the Pyrenees (see also discussion: Higgs, 2011; Mulder et al., 2011). Oscillatory water movements, responsible for the hummocky cross-stratification formation, may also be a result of internal waves (associated with pycnocline currents at the interface of two moving fluids with different densities, which may appear even at large depths exceeding several hundreds of metres (see, e.g., discussion in Basilici et al., 2012 and references therein).

Unfortunately, Filipek et al. (2017) did not discuss this problem. The authors did neither report the frequency of hummocky cross-stratification in their study area ["hummocky cross-stratification (HCS) was also observed"], which makes that the reader has no idea if this structure is widespread in the Podhale Flysch or it is rare and occurs at a certain level only. Reading the text, it can be traced that the hummocky cross-stratification was found in sections 525 and 579 in Kacwinianka (fig. 10G, H), but their location is unknown (it is missing in fig. 1C). Another two sites with hummocky cross-stratification are sections 635 and 558 (see fig. 9), both representing the uppermost part of the lower Zakopane beds (see their figs. 1C and 2). Interestingly, accumulation of the Zakopane beds (mudstone facies, mud-rich subflysch, distal flysch of various authors) is believed to have taken place during sea-level highstand associated with a simultaneous basin subsidence (e.g., Soták, 1998; Sotak et al., 2001). Although none of the previous papers gives an absolute value of water depth in the Polish part of the Podhale Basin during flysch deposition, but it can be indirectly deduced from data of the platform and pelagic stages that preceded the flysch deposition (Tatra Eocene and Globigerina Marl, respectively). Bartholdy et al. (1995) noted a deepening trend among biofacies in the Tatra Eocene, and estimated bathymetry of the youngest (deepest) ones between 20 and 80 m (Kulka, 1985 reports that nummulitic faunas preferred bottom depths not increasing 50-80 m; see also Soták, 2010: p. 398). Olszewska and Wieczorek (1998) reported a similar deepening distribution pattern of small foraminifera in the Tatra Eocene section; the uppermost biofacies contains species that prefer calm, relatively deep (outer shelf) waters. Grey marl that overlies Nummulitic rocks of the Tatra Eocene yielded benthic foraminifera that show upper bathyal (i.e. above $200 \mathrm{~m}$ ) depths of their accumulation (Olszewska and Wieczorek, 1998; see also Bartholdy et al., 1999, their 3rd Composite Sequence). If we assume that, after the pelagic stage and Eocene/Oligocene sea-level fall, an intense subsidence (see e.g., Sotak et al., 2001: fig. 12) took place simultaneously with Rupelian sea-level rise (3rd order cycles 4.4. and 4.5 of Haq et al., 1988) then the basin depth during deposition of the Zakopane beds most likely exceeded $200 \mathrm{~m}$. Acceptance of much shallower depths, not exceeding 40-50 m as deduced from authors' data, is difficult to explain in the light of the generally accepted basin geometry involving a basin length of several tens of kilometres with predominately eastward-oriented (nowadays; see Márton et al., 1999) palaeocurrent directions (Radomski, 1958; Marschalko and Radomski, 1960). 


\section{REFERENCES}

Alexandrowicz, S.W., Geroch, S., 1963. Association de petits Foraminifères dans l'Eocene de la Tatra (in Polish with French summary). Rocznik Polskiego Towarzystwa Geologicznego, 33: $219-228$.

Allaby, M. ed., 2008. A Dictionary of Earth Sciences. Oxford University Press, Oxford.

Barski, M., Bojanowski, M., 2010. Organic-walled dinoflagellate cysts as a tool to recognize carbonate concretions: an example from Oligocene flysch deposits of the Western Carpathians. Geologica Carpathica, 61: 121-128.

Bartholdy, J., Belass, S.M., Mertmann, D., Machaniec, E., Manutsoglu, E., 1995. Fazies-Entwicklung und Biostratigraphie einer Sequenz eozäner Sedimente im Steinbruch Pod Capkami, Tatra Gebirge, Polen. Berliner Geowissenschaften Abhandlungen, E16: 409-425.

Bartholdy, J., Bellas, S.M., Ćosović, V., Fuček, V.P., Keupp, H., 1999. Processes controlling Eocene mid-latitude larger foraminifera accumulations: modelling of the stratigraphic architecture of a fore-arc basin (Podhale Basin, Poland). Geologica Carpathica, 50: 435-448.

Basilici, G., de Luca, P.H.V., Poiré, D.G., 2012. Hummocky cross-stratification-like structures and combined-flow ripples in the Punta Negra Formation (Lower-Middle Devonian, Argentine Precordillera): a turbiditic deep-water or storm-dominated prodelta inner-shelf system? Sedimentary Geology, 267-268: 73-92.

Batten, D.J., 1991. Reworking of plant microfossils and sedimentary provenance. Geological Society Special Publications, 57: 79-90.

Berggren, W.A., Kent, D.V., Swisher, C.C. III, Aubry, M.-P., 1995. A revised Cenozoic geochronology and chronostratigraphy. SEPM Special Publication, 54: 129-212.

Bieda, F., 1946. Le stratigraphie du Flysch des Karpates centrales polonaises basée sur les grands Foraminifères (in Polish with French summary). Rocznik Polskiego Towarzystwa Geologicznego, 16: 1-58.

Bieda, F., 1948. Sur quelques foraminifères nouveaux ou peu connues du flysch des Karpates polonaises (in Polish with French summary). Rocznik Polskiego Towarzystwa Geologicznego, 18: 151-167.

Bieda, F., 1959. Paleontological stratigraphy of the Tatra Eocene and of the Podhale Flysch (in Polish with English summary). Biuletyn Instytutu Geologicznego, 149: 215-221.

Biffi, U., Manum, S.B., 1988. Late Eocene-Early Miocene dinoflagellate cyst stratigraphy from the Marche Region (Central Italy). Bolletino della Societè Paleontologica Italiana, 27: 163-212.

Brinkhuis, H., Biffi, U., 1993. Dinoflagellate cyst stratigraphy of the Eocene-Oligocene transition in Central Italy. Marine Micropaleontology, 22: 131-183.

Châteauneuf, J.-J., Gruas-Cavagnetto, C., 1978. Les zones de Wetzeliellaceae (Dinophyceae) du bassin de Paris. Bulletin du Bureau Recherches Géologiques et Minières, (2-ème Série), Section IV, 2-1978: 55-93

Dumas, S., Arnott, R.W.C., 2006. Origin of hummocky and swaley cross-stratification - the controlling influence of unidirectional current strength and aggradation rate. Geology, 34: 1073-1076.

Dumas, S., Arnott, R.W.C., Southard, J.B., 2005. Experiments on oscillatory-flow and combined-flow bed forms: implications for interpreting parts of the shallow-marine sedimentary record. Journal of Sedimentary Research, 75: 501-513.

Eldrett, J., Harding, I.C., Firth, J.V., Roberts, A.P., 2004. Magnetostratigraphic calibration of Eocene-Oligocene dinoflagellate cyst biostratigraphy from the Norwegian-Greenland Sea. Marine Geology, 204: 91-127.

Fensome, R.A., Williams, G.L., MacRae, R.A., 2009. Late Cretaceous and Cenozoic fossil dinoflagellates and other palynomorphs from the Scotian margin, offshore eastern Canada. Journal of Systematic Palaeontology, 7: 1-79.

Filipek, A., Wysocka, A., Barski, B., 2017. Depositional setting of the Oligocene sequence of the Western Carpathians in the Polish Spisz region - a reinterpretation based on integrated palyno- facies and sedimentological analyses. Geological Quarterly, 61 (4): 859-876.

Foster, C.B., O'Brien, G.W., Watson, S.T., 1986. Hydrocarbon source potential of the Goldwyer Formation, Barbwire Terrace, Canning Basin, Western Australia. Australian Petroleum Exploration Association Journal, 26: 142-55.

Garecka, M., 2005. Calcareous nannoplankton from the Podhale Flysch (Oligocene-Miocene, Inner Carpathians, Poland). Studia Geologica Polonica, 124: 353-369.

Gedl, P., 2000. Biostratigraphy and palaeoenvironment of the Podhale Palaeogene (Inner Carpathians, Poland) in the light of palynological studies. Part I, Part II. Studia Geologica Polonica, 117: 69-154, 155-303.

Gedl, P., 2004a. Dinoflagellate cyst record of the Eocene-Oligocene boundary succession in flysch deposits at Leluchów, Carpathian Mountains, Poland. Geological Society Special Publications, 230: 309-324.

Gedl, P., 2004b. Eocene dinoflagellate cysts from exotic clasts in a submarine slump, Podhale Flysch (Oligocene), Inner Carpathians, Poland. Studia Geologica Polonica, 123: 199-222.

Gedl, P., 2005. Late Eocene-early Oligocene organic-walled dinoflagellate cysts from Folusz, Magura Nappe, Polish Carpathians. Acta Palaeobotanica, 45: 27-83.

Gedl, P., 2014. Eocene dinoflagellate cysts from the Sołokija Graben (Roztocze, SE Poland): biostratigraphy and palaeoenvironment. Geological Quarterly, 58 (4): 707-728.

GedI, P., Suruło, M., 2005. Palynology of the Middle Eocene offshore sediments at Tenczyn, Magura Nappe, Flysch Carpathians, Poland. In: 5th Micropalaeontological Workshop MIKRO-2005 (eds. J. Tyszka and M. Oliwkiewicz-Miklasińska), Abstract Book: Lectures.

Grzybek, K., Halicki, B., 1958. Submarine slides in the Podhale Flysch (Carpathians) (in Polish with English summary). Acta Geologica Polonica, 8: 411-450.

Harms, J.C., Southard, J.B., Spearing, D.R., Walker, R.G., 1975. Depositional environments as interpreted from primary sedimentary structures and stratification sequences. SEPM Short Course, 2.

Haq, B.U., Hardenbol, J., Vail, P.R., 1988. Mesozoic and Cenozoic chronostratigraphy and cycles of sea-level change. SEPM Special Publication, 42: 71-108.

Higgs, R., 2011. 'Hummocky cross-stratification-like structures in deep-sea turbidites: Upper Cretaceous Basque basins (Western Pyrenees, France)' by Mulder et al. (2009), Sedimentology, 56, 997-1015: Discussion. Sedimentology, 58: 566-570.

Jackson, J.A. ed., 1997. Glossary of Geology. American Geological Institute, Alexandria, Virginia.

Jaromin, A., Kępińska, B., Nagel, J., Sokołowski, J., Wieczorek, J., 1992a. Dokumentacja geosynoptyczna otworu geotermalnego Biały Dunajec PAN-1 (in Polish). Geosynoptyka i Geotermia, 2: 1-121.

Jaromin, A., Kępińska, B., Nagel, J., Sokołowski, J., Wieczorek, J., 1992b. Dokumentacja geosynoptyczna otworu geotermalnego Poronin PAN-1 (in Polish). Geosynoptyka i Geotermia, 3: $1-88$.

Kempf, O., Pross, J., 2005. The lower marine to lower freshwater Molasse transition in the northern Alpine foreland basin (Oligocene; central Switzerland-South Germany): age and geodynamic implications. International Journal of Earth Sciences, 94: 160-171.

Köthe, A., 1990. Paleogene dinoflagellates from Northwest Germany - biostratigraphy and palaeoenvironments. Geologisches Jahrbuch A, 118: 3-111.

Köthe, A., 2009. Calcareous nannoplankton and dinoflagellate cysts Paleogene biostratigraphy of the Loburg I/90 cored borehole (Saxony-Anhalt, central Germany). Zeitschrift für Geologische Wissenschaften, 37: 381-425.

Köthe, A., Piesker, B., 2008. Stratigraphisches Vorkommen von Dinoflagellatenzysten (Dinozysten) im Tertiär von Deutschland. Bundesanstalt für Geowissenschaften und Rohstoffe, Hannover. 
Kulka, A., 1985. Arni sedimentological model in the Tatra Eocene. Kwartalnik Geologiczny, 29 (1): 31-64.

Luterbacher, H.P., Ali, J.R., Brinkhuis, H., Gradstein, F.M., Hooker, J.J., Monechi, S., Ogg, J.G., Powell, J., Rohl, U., Sanfilippo, A., Schmitz, B., 2004. The Paleogene Period. In: A Geologic Time Scale 2004 (eds. F.M. Gradstein, J.G. Ogg and A.G. Smith): 384-408. Cambridge University Press.

Mao, S., Wu, G., Li, J., 2004. Oligocene-early Miocene dinoflagellate stratigraphy, Site 11448, ODP Leg 184, South China Sea. Proceedings of the Ocean Drilling Project, Scientific Results, 184: 1-29.

Marschalko, R., 1964. Sedimentary structures and paleocurrents in the marginal lithofacies of the central-Carpathian flysch. Developments in Sedimentology, 3: 106-126.

Marschalko, R., Radomski, A., 1960. Preliminary results of investigations of current directions in the flysch basin of the Central Carpathians. Rocznik Polskiego Towarzystwa Geologicznego, 30: 259-272.

Márton, E., Mastella, L., Tokarski, A.K., 1999. Large counterclockwise rotation of the Inner West Carpathian Paleogene Flysch Evidence from paleomagnetic investigations of the Podhale Flysch (Poland). Physics and Chemistry of the Earth, Part A: Solid Earth and Geodesy, 24: 645-649.

Mulder, T., Razin, P., Faugeres, J-C., 2009. Hummocky cross-stratification-like structures in deep-sea turbidites: Upper Cretaceous Basque basins (Western Pyrenees, France). Sedimentology, 56: 997-1015.

Mulder, T., Razin, P., Faugčres, J-C., Gérard, J., 2011. Reply to the Discussion by Roger Higgs on 'Hummocky cross-stratification-like structures in deep-sea turbidites: Upper Cretaceous Basque basins (Western Pyrenees, France)'. Sedimentology, 58: $571-577$.

Olszewska, B., Wieczorek, J., 1998. The Paleogene of the Podhale Basin (Polish Inner Carpathians) - micropaleontological perspective. Przegląd Geologiczny, 46: 721-728.

Pieńkowski, G., Westwalewicz-Mogilska, E., 1986. Trace fossils from the Podhale Flysch Basin, Poland - an example of ecologically based lithocorrelation. Lethaia, 19: 53-65.

Pross, J., 2001. Dinoflagellate cyst biogeography and biostratigraphy as a tool for palaeoceanographic reconstructions: an example from the Oligocene of western and northwestern Europe. Neues Jahrbuch für Geologie und Paläontologie, Abhandlungen, 219: 207-219

Pross, J., Houben, A.J.P., van Simaeys, S., Williams, G.L., Kotthoff, U., Coccioni, R., Wilpshaar, M., Brinkhuis, H., 2010. Umbria-Marche revisited: a refined magnetostratigraphic calibration of dinoflagellate cyst events for the Oligocene of the Western Tethys. Review of Palaeobotany and Palynology, 158 213-235.

Radomski, A., 1958. The sedimentological character of the Podhale Flysch (in Polish with English summary). Acta Geologica Polonica, 8: 335-410.

Sachsenhofer, R.F., Leitner, B., Hans-Gert Linzer, H.-G. Bechtel, A., Ćorić, S., Gratzer, R., Reischenbacher, D., Soliman, A., 2010. Deposition, erosion and hydrocarbon source potential of the Oligocene Eggerding Formation (Molasse Basin, Austria). Austrian Journal of Earth Sciences, 103: 76-99.

Schiøler, P., 2005. Dinoflagellate cysts and acritarchs from the Oligocene-Lower Miocene interval of the Alma-1X well, Danish North Sea. Journal of Micropalaeontology, 24: 1-37.

Selley, R.C., 2000. Applied Sedimentology. Academic Press, San Diego.

Shanmugan, G., 2012. New Perspectives on Deep-water Sandstones. Origin, Recognition, Initiation and Reservoir Quality. Elsevier, Amsterdam

Sokołowski, J., 1992. Dokumentacja geosynoptyczna otworu geotermalnego Bańska IG-1 (in Polish). Geosynoptyka i Geotermia, 1: 1-122.

Soliman, A., 2012. Oligocene dinoflagellate cysts from the North Alpine Foreland Basin: new data from the Eggerding Formation (Austria). Geologica Carpathica, 63: 49-70.
Soták, J., 1998. Sequence stratigraphy approach to the Central Carpathian Paleogene (Eastern Slovakia): eustasy and tectonics as control of deep-sea fan deposition. Slovak Geological Magazine, 4: 185-190.

Soták, J., 2010. Paleoenvironmental changes across the Eocene-Oligocene boundary: insights from the Central-Carpathian Paleogene Basin. Geologica Carpathica, 61: 393-418.

Sotak, J., Pereszlenyi, M., Marschalko, R., Milicka, J., Starek, D., 2001. Sedimentology and hydrocarbon habitat of the submarine-fan deposits of the Central Carpathian Paleogene Basin (NE Slovakia). Marine and Petroleum Geology, 18: 87-114.

Starek, D., Fuksi, T., 2017. Statistical analysis as a tool for identification of depositional palaeoenvironments in deep-sea fans (Palaeogene formations, Central Western Carpathians, north Slovakia). Acta Geologica Slovaca, 9: 149-162.

Stover, L.E., Hardenbol, J., 1993. Dinoflagellates and depositional sequences in the Lower Oligocene (Rupelian) Boom Clay Formation, Belgium. Bulletin de la Société Belge de Géologie, 102: 5-77.

Stover, L.E., Brinkhuis, H., Damassa, S.P., de Verteuil, L., Helby, R.J., Monteil, E., Partridge, A.D., Powell, A.J., Riding, J.B., Smelror, M., Williams, G.L., 1996. Mesozoic-Tertiary dinoflagellates, acritarchs and prasinophytes. In: Palynology: Principles and Applications, 2 (eds. J. Jansonius and D.C. McGregor): 641-750. American Association of Stratigraphic Palynologists Foundation, Dallas, Texas.

Swift, D.J.P., Figueiredo, A.G.Jr., Freeland, G.L., Oertel, G.F., 1983. Hummocky cross-stratification and megaripples: a geological double standard? Journal of Sedimentary Petrology, 53: 1295-1317.

Śliwińska, K.K., Abrahamsen, N., Beyer, C., Brünings-Hansen, T., Thomsen, E., Ulleberg, K., Heilmann-Clausen, C., 2012. Bio- and magnetostratigraphy of Rupelian-mid Chattian deposits from the Danish land area. Review of Palaeobotany and Palynology, 172: 48-69.

Środoń, J., Kotarba, M., Biroń, A., Such, P., Clauer, N., Wójtowicz, A., 2006. Diagenetic history of the Podhale-Orava Basin and the underlying Tatra sedimentary structural units (Western Carpathians): evidence from XRD and $\mathrm{K}-\mathrm{Ar}$ of illite-smectite. Clay Minerals, 41: 751-774.

Țăbăra, D., 2017. Dinoflagellate cysts stratigraphy and palynofacies of Oligocene sequences in the northern Eastern Carpathians. Acta Palaeontologica Romaniae, 13: 49-63.

Tyson, R.V., 1995. Sedimentary Organic Matter. Organic Facies and Palynofacies. Chapmann and Hall.

Van Couvering, J.A., Aubry, M.-P., Berggren, W.A., Bujak, J.P., Naeser, C.W., Wieser, T., 1981. The terminal Eocene event and the Polish connections. Palaeogeography, Palaeoclimatology, Palaeoecology, 36: 321-362.

Van Gijzel, P., 1967. Palynology and fluorescence microscopy. Review of Palaeobotany and Palynology, 2: 49-79.

Van Simaeys, S., Munsterman, D., Brinkhuis, H., 2005. Oligocene dinoflagellate cyst biostratigraphy of the southern North Sea Basin. Review of Palaeobotany and Palynology, 134: 105-128.

Vasilyeva, O.N., 2013. Paleogene dinocysts from the eastern Caspian Depression (the Uspenskaya SP-1 well, Kazakhstan). Lithosphere, 1: 102-127.

Williams, G.L., Bujak, J.P., 1985. Mesozoic and Cenozoic dinoflagellates. In: Plankton Stratigraphy (eds. J. Bolli, K. Saunders and K. Perch-Nielsen): 847-964. Cambridge University Press, Cambridge.

Williams, G.L., Brinkhuis, H., Pearce, M.A., Fensome, R.A., Weegink, J.W., 2004. Southern Ocean and global dinoflagellate cyst events compared: index events for the Late Cretaceous-Neogene. Proceedings of the Ocean Drilling Project, Scientific Results, 189: 1-98.

Wilpshaar, M., Santarelli, A., Brinkhuis, H., Visscher, H., 1996 Dinoflagellate cysts and mid-Oligocene chronostratigraphy in the central Mediterranean region. Journal of the Geological Society, 153: 553-561. 